\title{
Situation and promotion of Young teachers scientific research of Independent college
}

\author{
Xuemei Wang ${ }^{1}$ Xiaofeng $\mathrm{Li}^{2}$ \\ 1 Department of Computer Science and Technology, Cheng-Dong College of Northeast Agricultural \\ University, Harbin 150025, China \\ Master2@163.com \\ 2 Department of Informatics and Science, Heilongjiang International University, \\ Harbin 150025, China \\ mberse@126.com
}

Keyword: Independent college; Young teachers; Scientific research ability

\begin{abstract}
Young teachers in independent colleges occupy larger proportion. The high ability of scientific research is crucial for the improvement of teaching quality and sustainable development of the college. The questions of independent college scientific research faced are less scientific research funds, unreasonable team structure of scientific research, low quality of scientific research, weak atmosphere of scientific research.Under the new situation, the independent colleges should take active attitude and effective measures to strengthen the cultivation with scientific research ability of teachers. A good interaction is form when combine teaching with scientific research. It can cultivate modernization talents with innovative consciousness and innovative ability which meet the requirements of times development.
\end{abstract}

\section{Introduction}

Independent college is a relatively independent school entity, which is exploration and innovation of higher education running system under the new situation.It is an effective way to speed up the development of higher education.The rapid development is a historic choice of Chinese higher education development. In addition to master the basic knowledge and skills required by modern enterprise, the students will have a certain research and innovation ability.Teachers should combine teaching with research and improve the comprehensive competitiveness of students in order to make independent college graduates was welcomed by the employing unit .Independent college teachers not only have profound knowledge but also have strong ability of practical skills and scientific research in order to achieve these needs ${ }^{[1-2]}$.

Caspar who is professor of Stanford university President think teachers who only seriously engaged in scientific research can more deeply understand the scientific law and grasp the essence of this discipline ${ }^{[3-4]}$, so as to impart knowledge better.Professor of new knowledge only by improving the teaching methods and teaching experience is impossible to achieve. Teachers make various disciplines knowledge overlapping seepage and expanding professional knowledge of the original scope by scientific research activities.It is beneficial to form a reasonable knowledge structure of teachers, promote the development of new knowledge and new ideas when injected new vitality to the traditional theory.It is beneficial to train teachers' creative thinking and innovation ability, then teachers naturally use this ability in the teaching and has a subtle penetration on the students so as to improve the students' study, strain and innovation ability ${ }^{[5]}$.

\section{Data statistics of scientific research status of young teachers of Independent college}

This article selects several representative in Harbin independent institute under the age of 40 young teachers as the research object.The questionnaire include main factors which influence the teachers' scientific research that are the teachers' degree, title structure, scientific research ability, scientific attitude (motivation) as well as scientific research management. It uses 200 questionnaires 200, acquires 172 effective questionnaires, and effective return ratio is 86 percent. 
Young teachers of college in quantity and structure. Structure of teacher education. Education structure reflects the professional quality and development potential of teachers in a some extent. Survey data shows that young teachers was 83.6 percent under the age of 40, 60 and older accounted for 15.3 percent of teachers and lack middle-aged backbone in independent college full-time teachers. Teachers age present structure of "two head big, middle small". The number of $\mathrm{PhD}$ are small in young teachers, the number of master's degree is more, about 53.4 percent, the proportion of teachers with a bachelor's degree is 45 percent,as shown in Figure 1.

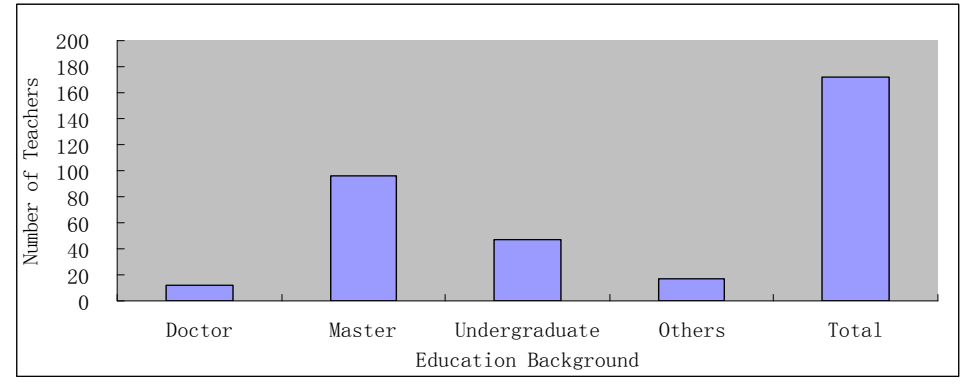

Fig. 1 Structure of Educational Background

Structure of teacher title.Title promotion of teachers has scientific research workload requirements, and the title is higher, the number of scientific research and quality requirements are also higher. So title structure is important symbol which measure teachers' scientific research ability and scientific research level.Survey shows that the lecturer title of young teachers accounted for 57.5 percent, 10.2 percent high and above title of professional teachers, as shown in Figure 2.

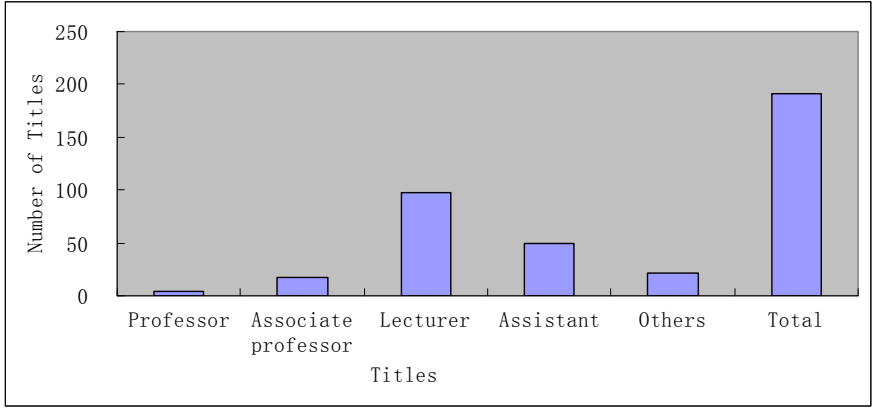

Fig. 2 Structure of Titles

Situation of published papers and undertake scientific research project.Scientific research findings is the most direct indicators that reflects scientific research level and research ability of teachers at colleges and universities.

Academic papers and works nearly three years. The quality of papers the teachers in independent college published is not high.Many of them are published in the general journal. Among published 138 papers, the number including EI, CPCI are 18, 7 papers published in Beijing University core journals, the rest are general publication. In terms of work, as the first editor accumulative total are 8 textbooks, deputy editor are 27 units, accounting for 6.5 percent of the total number of respondents.

Subject nearly three years.Teachers bear the subject are less and the scientific research level is low because the young teachers in independent college account for a large proportion. The more subject are college subjects, the less are above provincial research subjects which often appears in the form of self-financing. Only 12 national research subjects were won by associate professor in nearly three years.26 provincial research 1 subject were got. 69 college scientific research subject were bear by young teachers. Thus it can be seen that young teachers who can successfully apply for subject are very low.

Scientific research motivation with teachers. The current teaching quantity.Teaching work in the development of independent colleges occupy absolute position, college set up a wide variety of courses, teachers often act as different subjects and different professional teaching task.Teachers in the survey generally reflect that current teaching task occupying most time is relatively heavy,Results from survey show that workload up to 36 classes every weeks according to the teaching and practice teaching allocation to 36 weeks, at least 16 classes, average 20.12 classes were 
reached every week.Teachers spent times preparing courses and correcting students' papers in order to do a good job of teaching and complete the teaching mission. Young teachers have no more time and energy to accept new knowledge for scientific research, let alone to carry out the research.

Purpose of engaged in scientific research.The research also showed that 80.6 percent of those surveyed chose assess the title and promotion", 10.2 percent chose produce new scientific research achievements to own a sense of accomplishment, 6.5 percent chose get additional bonus.There are 2.7 percent of people choose complete the school every year as prescribed by the scientific research task.That is to say, most teachers have a certain pressure with title promotion. Teachers only research for title appraisal and published several papers.

Interesting in scientific research.Most of teachers who timely grasp latest developments in the area make themselves stand in the forefront of this field.They thought scientific research can promote the improvement of teaching level and quality and make the research of subject of themselves in the lead ,then promote academic development and professional transformation. But there is only 24.5 percent of respondents who said they believe that there is a need for scientific research and have interest in scientific research work. There are 14.2 percent of people who think that research are nothing. The rest of people said there are some interest but don't know how to begin.

Organization and management policy.Scientific research conditions.There are 2.8 percent of respondents who thought conditions with school scientific research are general. There are 76.3 percent of respondents who thought scientific research conditions are poor in college. Feedback are mainly as followed: lack of subject-leaders, lack of scientific research environment and teamwork opportunities. There are no mentor with experience and ability to guide young teachers. Information resources is not enough,there is not enough ways to acquire scientific information. There is no a complete scientific research funds because of little funds.

Communication of academic.Firstly,there is lack of team cooperation and communication consciousness in internal Institute.Secondly,there is less opportunity to participate in academic exchanges at home and abroad.Finally, there is lack of cooperation and communication with other colleges and universities, enterprises, government, etc. There is 63.6 percent of respondents who thought academic communication of college is not enough. There is no exchanges and training opportunities.

To sum up, although most of independent college young teachers who engaged in scientific research work have certain interest, most of the teachers are not enough attention to scientific research work at present. The research time is restricted by heavy teaching task. The papers of teachers publish and apply subject for the title promotion needs in Independent colleges, and most teachers think that scientific research achievements are achieved by the published several papers. Young teachers who undertake project are less are seldom involved the actual research work. In the long term, the independent college must research echelon fault, thus build a collaborative, strong scientific research team has a long way. To some extent, factors about lack of project entire journey management program restricted the scientific research work.

\section{Cultivate young teachers about the ability of scientific research in Independent college The reasonable arrangement with young teachers' teaching and scientific research tasks.} One of the direct causes of influence research development is teacher's teaching burden.Most young teachers have received higher education and have skill in professional direction. Young teachers who glad to accept the new task have energetic and a strong participation enthusiasm, then work hard and quickly accept new things. The main problems of improving teachers' professional quality in Independent college should grasp the cultivation of teachers' scientific research ability and setting up reasonable professional and curriculum. According to different teacher's professional expertise, carry out the corresponding teaching and scientific research tasks. Teachers who have abundant time to working in scientific research combine scientific research with the teaching which can coordinate the relationship between the scientific research and teaching.

Carry out academic exchanges. Scientific research activities are difficulty carry out and the 
success rate is low, because young teachers who have not enough experience to apply for the subject,not familiar with the process of scientific research etc.According to this situation, schools should vigorously carry out academic exchanges and invited experts, scholars and enterprises staff to carry out the scientific lectures about different subject development trends, timely guide and innovate scientific nature and feasibility of topic selection which keep young teacher accumulated quickly declare project methods and techniques.

A powerful scientific research team. In view of the teachers scientific research weakness, independent colleges should accelerate the construction of scientific research team, change of teachers structure, optimize the team structure. College can select and cultivate high academic level of the leader who are teachers who have a batch of good professional spirit and clear research direction in the collage according to the subject set up.The team which is based on research absorb the young teachers to join,make scientific research team in the title, educational background, knowledge level and study ability gradually rationalization. "Learning by doing" scientific training method, strengthening teachers' scientific research consciousness, make the youth teachers' scientific research ability, get exercise and improve in practice.

Improve the management of scientific research institutions.Independent college scientific research management departments should give full play to the functions of management and service, establish and improve the scientific research information system. They timely release of agencies at all levels of scientific research plan and research topic.Increases the chances of young teachers to participate in the project and host topic.The way not only improve teachers' scientific research ability but also improve the social popularity and reputation of the school.

In scientific prophase,old teachers should give appropriate guidance to help young teachers choice and control project application,then get reasonable budget and try to avoid blind choice and unreasonable declaration lead to project failure during the reporting issues. During the process of scientific research, they should timely pay attention to young teachers whose progress of scientific research subject so as to help or guide them to solve the difficulties among scientific research, to promote a high level, high-quality scientific research achievements.

\section{Summary}

In an increasingly competitive day, scientific research level of young teachers in colleges and universities that restricts the improvement of teaching level is the key to the sustainable development of independent college. Independent college strengthen the cultivation of the teachers' scientific research ability,then make teachers who become a fine, innovative teachers by improving the scientific research conditions, constructing echelon of scientific research, reducing the teaching task, setting up scientific research platform. It can combine scientific research, subject construction with talent cultivation.

\section{References}

[1] Fang Guocai.The Orientation and Features of University--The Enlightenment on the Observation of American Higher Education[J] .Journal of Jiangsu Institute of Education(Social Science Edition). 2008,1:1-9

[2] Wen Chaoqun,Xionggaoqiang.Teaching research university young teachers scientific research present situation and the way to ascension[J]. Cultural and educational

information.2012,12:190-192

[3]Xuan Lina,Zhang Junzhong,He Rongbing.Independent College teachers scientific research competitiveness management research[J].Journal of Guizhou Normal College. 2012,12:51-53

[4]LiaoYu Independent School Organization Culture Construction [J].Human Resource Management,2013,01:131-134.

[5]Wang Fang. From the perspective of psychological contract of independent college teachers stability study [J]. Journal of Guangxi College of education, 2013,01:61-65 